\title{
Effect of corporate social responsibility, good corporate governance and ownership structure on financial performance and firm value: A Study in Jakarta Islamic Index
}

\author{
Amiruddin Jallo ${ }^{1)}$, Abdul Rahman Mus ${ }^{2)}$, Mursalim ${ }^{3)}$, Suryanti $^{4)}$ \\ 1) (Doctoral Student in the Faculty of Economics, University of Indonesia Muslim \\ ${ }^{2,3,4)}$ (Faculty of Economics, University of Muslim Indonesia)
}

\begin{abstract}
This study explores several of the problems that are the objectives of this study: (1) Effect of corporate social responsibility, good corporate governance and ownership structure of financial performance. (2) Effect of corporate social responsibility, good corporate governance, ownership structure and financial performance of the value of the company. (3) Effect of corporate social responsibility, good corporate governance and ownership structure on corporate value through financial performance. The research population this is a 30 companies listed on Jakarta Islamic Index (JII) period in 2013 to 2015. There are 28 companies as a research sample. Sampling technique used is purposive sampling. The analysis technique used is partial least squares (PLS) with the help of SmartPLS version 3.0 analysis program. The results show that: (1) corporate social responsibility, good corporate governance and ownership structure has a positive and significant effect on financial performance. (2) Corporate social responsibility and ownership structure has a positive and insignificant effect on firm value. (3) Good corporate governance has a positive and significant effect on firm value. (4) Corporate social responsibility and ownership structure have a positive and insignificant effect on firm value as a mediated financial performance. (5) Good corporate governance has a positive and significant effect on firm value as a mediated financial performance.
\end{abstract}

Keywords: Corporate social responsibility, good corporate governance, ownership structure, financial performance, firm value

\section{Introduction}

Maximizing the firm value is very important for a company as to maximize value also means maximizing shareholder wealth which is the company's main purpose. Firm value reflected in the share price means that the higher the stock price, the higher the value of the company. The company's value can increase the wealth of the shareholders, so shareholders will invest their capital to the company (Haruman 2008; cited in Permanasari, 2010). The phenomena that occur in the Indonesia Stock Exchange show that the value of a company in the Proxy with a stock market value changes although no financial policy of the company. The company's value may change due to other information such as the social and political situation, because that information can influence the policy pursued by the company.

Companies are expected to always increase the firm value from year to year. In fact the company that was in Indonesia mostly has a small company value and has fluctuated from year to year. Fluctuations in the value of companies that sometimes rise or fall can cause problems, as the company will lose its appeal in the stock market (Wijaya \& Wibawa, 2010). These factors can be summarized into a single entity in which everything can be arranged in good corporate governance (GCG) implementation through mechanisms such as managerial ownership, institutional ownership, independent directors, and audit committee as a mechanism GCG holds the highest authority in determining policy or decision to be taken by the company. Information on the company's performance and value of companies in the companies listed in the Jakarta Islamic Index (JII) decreased, thereby reducing investor confidence. It is based on empirical data on Book Value Price (PBV) and Return on Assets (ROA). The development of financial performance and value listed company in Jakarta Islamic Index (JII) can be seen in the following table:

Table 1. Financial Performance and firm value in companies listed on the Jakarta Islamic Index (JII)

\begin{tabular}{|l|c|c|c|c|c|}
\hline \multicolumn{1}{|c|}{ Company Performance } & $\mathbf{2 0 1 1}$ & $\mathbf{2 0 1 2}$ & $\mathbf{2 0 1 3}$ & $\mathbf{2 0 1 4}$ & $\mathbf{2 0 1 5}$ \\
\hline Financial Performance (ROA) & $12,37 \%$ & $10,25 \%$ & $9,35 \%$ & $8,59 \%$ & $6,33 \%$ \\
\hline Firm value (PBV) & $4,75 \%$ & $3,50 \%$ & $3,78 \%$ & $4,05 \%$ & $4,12 \%$ \\
\hline
\end{tabular}


The phenomenon of ROA is decreasing from $12.37 \%$ to $6.33 \%$ and then in 2013 is a decline at PBV of 4.75 to 3.78. The decline in financial market conditions which impact the Islamic capital market. But in 2014 when the financial performance (ROA) decreased from $9.35 \%$ to $6.33 \%$ in 2015 , precisely firm value (PBV) increased from 3.78 in 2013 to 4.12 in 2015 . The assessment of the value of the company only illustrates one side only; therefore it is necessary to mention the additional data to better. The current economic decision making, not merely consider the value of the company to measure the financial performance of the entity, but there are other factors into consideration investors namely non-financial or social information reported in the annual report. This encourages companies faced with the triple bottom lines that disclosure of the financial aspects (profit), social (people) and the Environment (planet) simultaneously. Report that relates to three aspects of the report was known as sustainability reporting. Sustainability reporting is a disclosure, measurement, and accountability efforts of the organization's performance to the achievement of stakeholders development goals of internal and external. The companies not only optimize the performance of company profits alone, but also participate in community care for the environment, known as Corporate Social Responsibility (CSR).

CSR is one factor that affects the value of the company as one of the basic ideas underlying the CSR is currently regarded as the essence of business ethics is the realization that the companies not only has economic obligations and legal to the shareholders, but also have a duty Social toward stakeholder. CSR is not longer an option but rather can be regarded as a duty that must be done to maintain the natural balance equation. It is stipulated in Law No. 40 of 2007 on Limited Liability Company (PT) explains that companies whose business activities in or relating to the natural resources required to implement social and environmental responsibility. The setting of CSR today is no longer voluntary / commitments by the company in its activity account, but are mandatory / making obligation for the company to carry out or implement it. Article 74 of Law Company Limited declares that: (1) The Company runs its business activities in the field and / or related to the natural resources required to implement the Social and Environmental Responsibility (TJSL). (2) TJSL is an obligation of the Company budgeted and accounted for as an expense of the Company that the implementation is done with due regard to decency and fairness. (3) The Company did not carry out the obligations sanctioned in accordance with the provisions of the legislation. With the absence of these, especially the limited liability companies engaged in or related to natural resources have to carry out its social responsibility to the community.

The success of the business is determined by how its contribution to the welfare of the general public, not only for residents of the business itself (Bowen, 2008). An entity in the operations cannot be separated from the community and the surrounding environment, thus creating a reciprocal relationship between the community and the company. The company needed a positive response from the community obtained through what is done by the company to its stakeholders, including the community and the surrounding environment. CSR is a form of corporate responsibility in correcting social inequality and environmental damage caused by the company's operational activities. More forms of liability by the company to the environment, image corporate to be increased. Investors are more interested in companies that have a good image in the community for the better image of the company, the higher customer loyalty. With increasing consumer loyalty, then sales will increase and profitability continue to grow? This causes the smooth running of the business, so the company's value will increase. The picture shows the CSR can improve the profitability and value of the company.

The disclosure of CSR in report the annual report reinforce the company's image and became as one of the considerations is concerned investors or prospective investors to choose the place for investment because it considers that the company is providing the image to the public that the company is no longer just the pursuit profit only but already attention to the environment and society (Anwar et al., 2010). By implementing CSR corporate image, the better so that the higher customer loyalty. With the increasing consumer loyalty for a long time, then the sale of the company is getting better and in the end with the implementation of the CSR, the expected level of corporate profitability also increased (Satyo, 2005). Therefore, CSR plays an important role in increasing the firm value as a result of increased sales of the company by carrying out various social activities in the surrounding neighborhood. Companies disclose (CSR) have better financial performance compared with it's slightly disclose such information (Lajili \& Zeghal, 2006). The relationship between social and environmental performance of companies with financial performance (ROE and ROA) showed a positive relationship (Mahoney, 2003). The environmental performance of the positively influence Economic performance (Suratno, 2006). Hackston \& Milne (1996) reported that the disclosure of social responsibility does not significantly affect the profitability. Fauzi (2004) concluded that the practice of social responsibility negatively affect the financial performance.

The effect of CSR on Firm Value is a positive (Connelly et al, 2012 Mecca \& Ballesta, 2011). This assumption is supported Legitimacy Theory found legitimacy can be acquired when the company's presence does not interfere with or in accordance with the existence of values in society (Deegan, Robin, \& Tobin, 2002). Stakeholder Theory also stated that the satisfaction of each stakeholder group is a support instrument for Corporate Performance (Jones, 1995). Waddock \& Graves (1997) also states in the so-called Stakeholder Theory in explained of corporate social responsibility, in conjunction with stakeholders will enhance the 
competitive advantage and financial performance. Companies that are considered by stakeholders have a good reputation will make the company easier to get a good financial position through the market mechanism. That's necessary Good Corporate Governance (GCG), in order to conduct business people have directives that can be referenced. In the last decade, GCG has become a term that is so warm and movements discussed global institutions such as the IMF, the Word Bank, APWC, OECD and ADB were taking part in the implementation of GCG consistently in the corporate world. This impulse is motivated several problems, among others stems from the financial crisis from a variety of areas, ranging crisis in Mexico in 1995 and the crisis in Thailand in 1997 and then transformed into the Asian financial crisis, including in Indonesia. Many parties felt that this financial crisis is seen as a result of weak corporate governance practices (Frankl 2007).

Tumirin (2007), stating their GCG implementation will affect the achievement of the company's value. Companies would have to assure investors that the funds they invest for financing activities, investment, and growth of the company are used appropriately and efficiently and ensure that management acts in the best interest of the company. Implementation of GCG can be driven from two sides, namely ethics and regulations. Encouragement of ethical driven comes from the awareness of individual businesses to run a business practice that promotes the survival of the company, the interest's stakeholders' and avoid the ways to create a quick profit. While the impetus of regulator driven force the company to comply with the legislation in force (General Guidelines of Good Corporate Governance in Indonesia, 2006). From an academic background, GCG needs arising in connection with the agency theory. Implementation of GCG helpful expected to increase and maximize the value of perusahaan.GCG expected to seek a balance between the different interests that can benefit the company as a whole.

The process to maximize value would arise a conflict of interest between managers and shareholders, we called agency problem. Infrequently the management that the company's managers have goals and other interests that conflict with the main purpose of the company and often ignores the interests of shareholders. Divergence of interests between managers and shareholders have resulted in the emergence of conflict is commonly called agency conflict, it happens because the manager a personal interest, otherwise the shareholders do not like the personal interest of the manager because of what the manager will add to the cost for the company, causing a decrease in profits companies and influence stock prices, thus lowering the value of the company (Jensen \& Meckling, 1976). Agency Theory developed into a managerial issue after the inclusion of the issue of control results or forms of behavioral terms. The manager understood as agents who pursue personal interests against the interests of the owners or shareholders of Investment Company which would create residual-loss, because the manager's personal interests (Jensen \& Meckling, 1976). The businesses will seek to curb unnecessary costs (residual-loss) to supervise and sanction managers through the installation of control systems and incentives. The most important of the control system is a full-strength board of directors formed independently, formed from an outsider who oversees the executives on behalf of shareholders (Fama \& Jensen, 1983, in Donaldson, 1995). While incentives or encouragement in question is a leadership meeting of shareholders trying to align the interests of the owner of managers, by making engagement in creating a symmetrical relationship. When plans for effective supervision and sanctioning or also the practice of bonds is not the case, the manager will rig the owners through unduly high salaries, benefits, extra income, and leisure time during normal business hours and in a way the most cunning is a diversified legal entity or avoid the risk (Donaldson, 1995).

The background of the development of this theory, developed according to the needs of the modern enterprise. C. Berle \& Means (1932) illustrate the separation of owners and controllers as a typical firm 20century. The big companies they think are owned by many shareholders, so as such is not an owner who has the power to control the actions of the employees in the company. GCG is a form of good corporate governance, in which is included a form of protection against the interests of shareholders (public) as the owner of the company and its creditors as external funding system. Good corporate governance that will provide effective protection to shareholders and creditors to obtain a reasonable return on investment, precisely and efficiently as possible, and to ensure that management acts as best she could do for the benefit of the company (Bukhaari, 2012). Corporate governance as a mechanism for the organization as good governance in managing the organization's resources in an efficient, effective, economical or productive with the principles of transparency, accountability, responsibility, independent, and fair in order to achieve organizational goals. Good corporate governance can be viewed in terms of the organization's internal mechanism or mechanisms external to the organization. Internal mechanism is more focused on how the leadership of an organization set the course of the organization in accordance with the principles set out above (Syakhroza, 2005).

Organization for Economic Co-operation and Development (OECD) defines GCG with a set of relationships between the management, company's board and shareholders and others who have an interest in the company. GCG required in their structures, devices to achieve the objectives and the monitoring of performance. With their one of GCG mechanism is expected to monitor the company managers can more effectively so as to improve the company's performance and corporate value. So if companies apply corporate 
Effect of corporate social responsibility, good corporate governance and ownership structure on ..

governance system is expected to increase the performance to be better, with the increase in the company's performance is also expected to enhance the company's stock price as an indicator of the value of the company so that the company's value will be achieved (Carningsih, 2009). Corporate governance is a critical aspect in the management of the company. The study of Black et al. (2003) showed a strong positive correlation between corporate governance and the market value of the company. Joh (2003) found that practices corporate governance poor lead to lower performance. Research on corporate governance many of which focuses on the characteristics of the board of directors and audit committee of the company. Research conducted Beasley (1996) found that companies that commit fraud have external commissioners percentage significantly lower than companies that do not cheating. Darmawati et al. (2004) proved that the application of corporate governance positively related to the company's operational performance. Veronica \& Bachtiar (2004) find that audit committees have a significant effect on earnings management. However, in other parts, Wedari (2004) actually found that corporate governance is positively related to earnings management. That is, the practice of corporate governance in Indonesia is ineffective, has not been able to protect investors from selfish actions undertaken manager. There are some previous research on corporate governance and CSR on company performance. Daily et al. (1998), Deloitte \& Tauche (1996); cited in Kakabadse et al. (2001); Young (2003). On the other hand according to Gompers et al. (2003) found a positive relationship between corporate governance indexes with a long-term company performance. Klapper \& Love (2002) found a positive relationship between corporate governance and corporate performance (Mitton, 2000; Darmawati, 2004).

GCG research has been measured by the mechanism of corporate governance by focusing on four factors: the number of board of directors, the proportion of independent board, audit committee members and shareholdings. But in this study, written board remuneration and corporate ethics, so that factor remuneration and corporate ethics that shows the differences in this study with previous research. Some basic considerations in this study so that the board remuneration and ethical corporate important role in improving the performance of the company, according to the theory of motivation on compensation given to someone will increase the motivation to work and ultimately can improve the performance, including the company's performance and value of companies

The ownership structure is explained by two perspectives, the approach of institutions and information asymmetry approach. The approach considers ownership structure of the body as an instrument or tool to reduce conflicts of interest between various claim holders. Approach the mechanisms of information imbalance ownership structure as a way to reduce the information asymmetry between insiders and outsiders through the disclosure of information on capital market. Faisal (2004) found that managerial ownership is negatively related to agency costs as measured by asset turnover and positively associated with operating expense. It shows that managerial ownership as a mechanism not yet fully functional enterprise asset utilization and yet can suppress managerial discretion. Furthermore, the board size is positively related to the cost to agency and negatively related to operating expense. Instead, it raises questions as opposed to agency theory predicts that the larger the size of the board, the greater the operating costs. According to Wahyudi (2006) the unification of the interests of shareholders, debt holders, and management which in fact is the parties who have an interest in the Destination the company on several occasions caused agency problem. Agency problems can be influenced by the ownership structure (managerial and institutional ownership) Ownership Structure by some investigators believed to influence the course of the company, which in turn affects the company's performance in achieving corporate goals of improving corporate value. It is caused by the absence of control to which they apply. Some research on the ownership structure and financial decisions ever made by Crutchley (1999) to build a model that shows four interrelated decisions regarding leverage, dividend, insider ownership and institutional ownership simultaneously determined within the framework of the agency cost. In his research Crutchley (1999) also show that institutional ownership is the substitution of managerial ownership. Chen (2000) found a negative relationship between analyst coverage and the managerial ownership; it supports research Crutchley (1999) Optimization of the value of the company which is the company's goals can be achieved through the implementation of the financial management function, where the financial decisions taken will affect financial decisions more and impact on the enterprise value (Fama \& French, 1998).

Ownership Structure affects on financial performance and firm value (Wahla et al, 2012; Shah et al., 2012; Connelly et al, 2012; Mecca \& Ballesta, 2011). This assumption is supported by the Agency Theory, which explains how the parties behave in the company, because basically between the agent and the principal have different interests that lead to a conflict of interest (Jensen \& Meckling, 1976). Agency theory considers ownership structure as an instrument or tool to reduce conflicts through increased managerial ownership or institutional ownership (Leland \& Pyle; Cited in Suranta \& Machfoedz, 2003).

Financial performance is the view of the financial condition of the company for a certain period. The financial performance also often informed by the company. The financial performance is the result of many decisions is made constantly by the Management Company to achieve a certain goal effectively and efficiently (Anwar et al., 2010). Many things become a benchmark for the performance of a company, for example, is the 
company's ability to generate profits. Profit company other than an indicator of a company's ability to meet obligations to the owners of capital, is also an element in the creation of value for companies that demonstrate the company's prospects in the future. Research on the effects of the financial performance of the company's value among Ulupui (2007) describes the theory underlying these studies. Other performance assessment can also be seen on the company's ability to generate profits (Rahayu, 2010). Profit Company other than an indicator of a company's ability to meet obligations to persons with funds is also an element in the creation of value for companies that demonstrate the company's prospects in the future. The low quality of earnings will make decision-making errors of the wearer such as investors and creditors, so the value of the company will be reduced (Siallagan \& Machfoedz, 2006). These means more and better support the notion that financial performance is obtained, the higher the value of the company. In measuring the performance of companies investors usually look at the financial performance reflected a wide range of ratios. Return on Equity (ROE) and Return on Assets (ROA) is an example of an important indicator that is often used by investors to assess the level of profitability of the company before making an investment. One of the main reasons the company operates is useful to generate profits for shareholders. The size of the successful achievement of these reasons is the larger the ROE and ROA reflects the company's ability to generate high returns for shareholders. This has an impact on the increased value of the company. The influence of the financial performance of the company's value, as did Zuraedah (2010) provide evidence that the variables tested, namely ROA, CSR and the interaction between the ROA and CSR effect its significant on firm value in the proxy with Tobin's Q

The measurement of firm value can be measured by Price Earning Ratio (PER) and Price Book Value (PBV) and Tobin's Q, because it not only gives an overview on the fundamental aspects, but also the extent to which the market valuing the company of various aspects seen by outsiders, including investors. Tobin's $Q$ represents a number of important variables in measuring performance, among other assets of listed companies; market trends are adequate as the views of analysts about the prospects of the company, and variable intellectual capital or intangible assets. Specifically, Tobin's or Q-ratio is often used as a measure of the value of intangible assets or intellectual capital of a company such as monopoly power, managerial system (corporate governance and social responsibility) and growth opportunities. Because of the intangible assets of a company it is often judged more by the market.

\section{Literature review and hypothesis Development}

\subsection{Corporate social responsibility $(\mathrm{CSR})$}

Financial performance can be measured by financial ratios, such as ROA, ROE, sales growth and other ratios (Wahyuningsih, 2012: 2). According to Kurnia (2013), the disclosure of which is increasingly widespread will give a positive signal to the parties interested in the Company (stake holders) as well as the shareholders of the Company.

$\mathrm{H}_{1 \mathrm{a}} \quad$ Corporate Social Responsibility is a positive and significant effect on financial performance.

$\mathrm{H}_{1 b} \quad$ Corporate Social Responsibility is a positive and significant effect on firm value.

$\mathrm{H}_{1 \mathrm{c}} \quad$ Corporate Social Responsibility is a positive and significant effect on firm value as a mediated financial performance.

\subsection{Good Corporate Governance (GCG),}

The effective of corporate governance in the long term can improve the performance of the company and benefit shareholders (Kusumawati, 2005). Improved performance of the company is not only for shareholders but also for the general public interest.

$\mathrm{H}_{2 \mathrm{a}} \quad$ Good Corporate Governance is a positive and significant impact on financial performance.

$\mathrm{H}_{2 b} \quad$ Good Corporate Governance is a positive and significant impact on firm value.

$\mathrm{H}_{2 \mathrm{c}}$ Good Corporate Governance is a positive and significant impact on firm value as mediated financial performance.

\subsection{Ownership structure (OS)}

Institutional Ownership shown by the high percentage of shares owned by the institution, in this case in the form of, insurance, banks, investment companies and private companies.

$\mathrm{H}_{3 \mathrm{a}} \quad$ Ownership structure is positive and significant impact on financial performance.

$\mathrm{H}_{3 \mathrm{~b}} \quad$ Ownership structure is positive and significant impact on firm value.

$\mathrm{H}_{3 \mathrm{c}} \quad$ Ownership structure is positive and significant impact on firm value as a mediated financial performance.

\subsection{Financial Performance (FP) and Firm value (FV)}

The financial performance of companies that are considered by stakeholders have a good reputation will make the company easier to get a good financial position through the market mechanism. Firm value is reflected in the share price means that the higher the stock price, the higher the value of the company. The 
company's value can increase the wealth of the shareholders, so shareholders will make an investment to the company (Haruman, 2008; Cited in Permanasari, 2010).

$\mathrm{H}_{4} \quad$ Financial Performance is a positive and significant impact on firm value

\section{Methods}

This study used two approaches, namely descriptive research and explanatory research. This study was performed on companies listed in the Jakarta Islamic Index (JII) and as for the time required to do research for three (3) months. The data used in this research is secondary data. Secondary data is data obtained from documents and financial reports (annual report or annual report) issued by each company through IDX Indonesia Stock Exchange, Statistics Capital Market, and written reports other than the results of the study of literature, references, documents, and printed materials more and regulations relevant to this study. The population in this study are all companies listed on the Jakarta Islamic Index of 30 (thirty) of the company during the period of 2013-2015. Total sample of companies listed on the Jakarta Islamic Index of 28 (twenty eight) companies.

\subsection{Outer model}

\section{Analysis and Discussion}

Construct validity of measurement models with reflective indicators can be measured by a score of loading factor and using the parameters Average Variance Extracted (AVE), and Cronbach Alpha (Jogiyanto and Abdillah, 2009). A construct declared valid if the value of factor loadings > 0.6, AVE > 0.5, Cronbach Alpha $>0.6$.

Table 2. Outer Loading, AVE and Cronbach's Alpha

\begin{tabular}{|c|c|c|c|c|}
\hline \multicolumn{2}{|c|}{ Construct } & Factor loadings & \multirow{4}{*}{$\frac{\text { AVE }}{0,661}$} & cronbach's alpha \\
\hline \multirow[t]{3}{*}{$\operatorname{CSR}\left(\mathrm{X}_{1}\right)$} & $\mathrm{X}_{11}=$ Economy & 0,896 & & \multirow[t]{3}{*}{0,769} \\
\hline & $\mathrm{X}_{12}=$ Environmental & 0,801 & & \\
\hline & $\mathrm{X}_{13}=$ Social & 0,733 & & \\
\hline \multirow[t]{5}{*}{$\operatorname{GCG}\left(\mathrm{X}_{2}\right)$} & $\mathrm{X}_{21}=$ directors & 0,756 & \multirow[t]{5}{*}{0,660} & \multirow[t]{5}{*}{0,881} \\
\hline & $X_{22}=$ Owners & 0,812 & & \\
\hline & $\mathrm{X}_{23}=$ Transparency & 0,836 & & \\
\hline & $\mathrm{X}_{24}=\mathrm{B}$. Remuneration & 0,846 & & \\
\hline & $\mathrm{X}_{25}=\mathrm{C}$. Ethics & 0,808 & & \\
\hline \multirow[t]{2}{*}{ O. structure $\left(\mathrm{X}_{3}\right)$} & $\mathrm{X}_{31}=$ Institusional & 0,694 & \multirow[t]{2}{*}{0,778} & \multirow[t]{2}{*}{0,090} \\
\hline & $\mathrm{X}_{32}=$ Managerial & 0,752 & & \\
\hline \multirow[t]{2}{*}{ F. performance $(\mathrm{Y})$} & $\mathrm{Y}_{1}=\mathrm{ROA}$ & 0,909 & \multirow[t]{2}{*}{0,774} & \multirow[t]{2}{*}{0,717} \\
\hline & $\mathrm{Y}_{2}=\mathrm{ROE}$ & 0,854 & & \\
\hline \multirow[t]{2}{*}{ Firm Value $(\mathrm{Z})$} & $\mathrm{Z}_{1}=\mathrm{PBV}$ & 0,948 & \multirow[t]{2}{*}{0,523} & \multirow[t]{2}{*}{0,688} \\
\hline & $\mathrm{Z}_{2}=$ Tobins $-\mathrm{q}$ & 0,763 & & \\
\hline
\end{tabular}

Based on the results of testing the outer models can be concluded that all the items have valid statement that is Factor loadings > 0.6, AVE> 0.5 and Cronbach Alpha >0.6 except, X3.3 Public Ownership, Y3 and Z3 PER CR, so this indicator is ignored and the results of other indicators can be analyzed further. Figure 1 below shows the structural model is executed using Samart PLS3 Alghorithm.

Figure 1. First Model

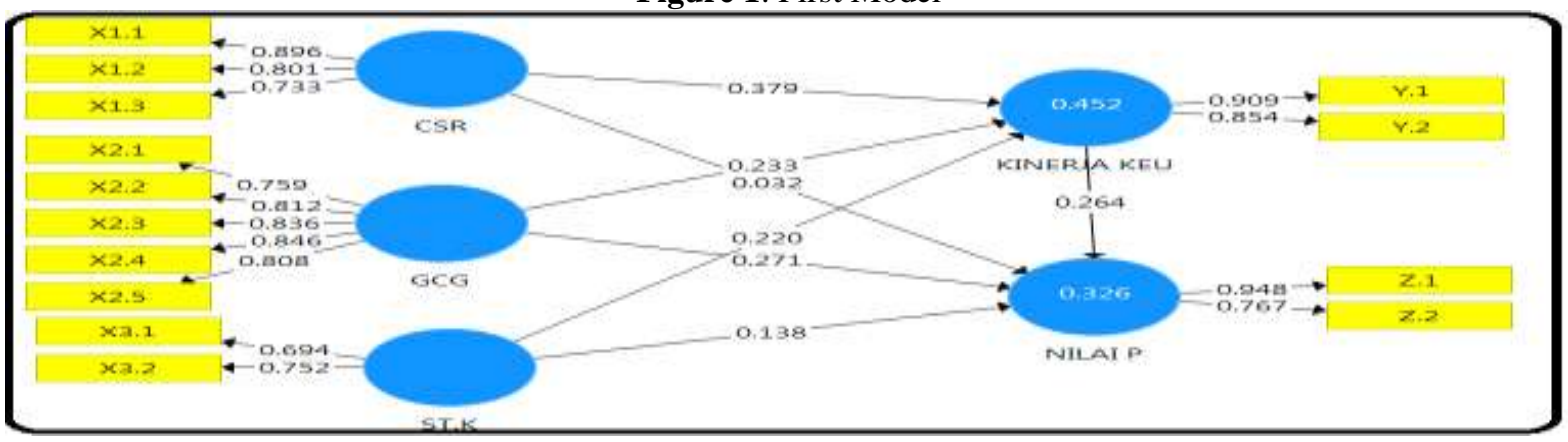

a. Convergent Validity

To assess the convergent validity of a construct can be done by looking at the score of average variance extracted (AVE) and communality, each of which must be a value above 0.5. Shown in Table 2 above that all AVE and Communality have a value above 0.5. It can be concluded that the construct has a good convergent validity. 
b. Discriminant validity

Discriminant validity of the measurement model (outer model) with indicators of reflective judged by cross loading measurements with the construct. If the correlation construct the measurement items larger than the other constructs, then it shows that the latent constructs predict the size of the block they are better than the size of the other blocks.

Table 3. Cross Loadings

\begin{tabular}{|l|c|c|c|c|c|}
\hline \multicolumn{1}{|c|}{ Construct } & \multirow{2}{*}{ CSR $\left(\mathrm{X}_{1}\right)$} & \multirow{2}{*}{ GCG $\left(\mathrm{X}_{2}\right)$} & \multirow{2}{*}{ F. performance $(\mathrm{Y})$} & Firm Value $(\mathrm{Z})$ & \multirow{2}{*}{ O. structure $\left(\mathrm{X}_{3}\right)$} \\
\cline { 1 - 4 } Indicators & 0.896 & 0.760 & 0.635 & 0.564 & 0.188 \\
\hline $\mathrm{X}_{11}$ & 0.801 & 0.563 & 0.403 & 0.147 & 0.099 \\
\hline $\mathrm{X}_{12}$ & 0.733 & 0.513 & 0.332 & 0.186 & 0.213 \\
\hline $\mathrm{X}_{13}$ & 0.614 & 0.759 & 0.773 & 0.546 & 0.407 \\
\hline $\mathrm{X}_{21}$ & 0.675 & 0.812 & 0.332 & 0.380 & 0.178 \\
\hline $\mathrm{X}_{22}$ & 0.592 & 0.836 & 0.321 & 0.273 & 0.130 \\
\hline $\mathrm{X}_{23}$ & 0.584 & 0.846 & 0.336 & 0.302 & 0.157 \\
\hline $\mathrm{X}_{24}$ & 0.680 & 0.808 & 0.339 & 0.339 & 0.247 \\
\hline $\mathrm{X}_{25}$ & 0.062 & 0.186 & 0.224 & 0.265 & 0.694 \\
\hline $\mathrm{X}_{31}$ & 0.228 & 0.273 & 0.311 & 0.214 & 0.752 \\
\hline $\mathrm{X}_{32}$ & 0.530 & 0.545 & 0.909 & 0.527 & 0.400 \\
\hline $\mathrm{Y}_{1}$ & 0.544 & 0.513 & 0.854 & 0.331 & 0.241 \\
\hline $\mathrm{Y}_{2}$ & 0.489 & 0.540 & 0.541 & 0.948 & 0.309 \\
\hline $\mathrm{Z}_{1}$ & 0.173 & 0.247 & 0.241 & 0.767 & 0.258 \\
\hline $\mathrm{Z}_{2}$ & & & &
\end{tabular}

The table indicates discriminant validity good as an indicator of construct correlation value is higher than the value of the correlation indicator other constructs. As an illustration of factor loadings $Y_{1}$ with the use of Financial Performance ( $\mathrm{Y}$ ) is equal to 0,909. This amount is higher than factor loadings $\mathrm{Y}_{1}$ with other constructs, namely CSR $\left(\mathrm{X}_{1}\right)$, GCG $\left(\mathrm{X}_{2}\right)$, and Firm value $(\mathrm{Z})$ as well as the ownership structure $\left(\mathrm{X}_{3}\right)$ of 0,530 ; $0545 ; 0,257$ and 0,400. In addition, the table also shows that the correlation firm value $(\mathrm{Z})$ constructs with the indicator was higher than the correlation indicator $\left(\mathrm{Z}_{1}\right)$ with other constructs. Something similar happened to the construct of CSR $\left(\mathrm{X}_{1}\right)$, and GCG $\left(\mathrm{X}_{2}\right)$. As well as the ownership structure $\left(\mathrm{X}_{3}\right)$, so it can be concluded that the latent constructs predict indicators on the block they are better than the indicator in the other block. Reliability and construct validity of the measurement model with a reflexive indicators can be measured by looking at the value of composite reliability, cronbach's alpha and AVE block indicator that measures the construct.

Table 4. Composite Reliability, cronbach's alpha and AVE

\begin{tabular}{|l|c|c|c|}
\hline \multicolumn{1}{|c|}{ Construct } & Composite Reliability & cronbach's alpha & AVE \\
\hline CSR $\left(\mathrm{X}_{1}\right)$ & 0,853 & 0,769 & 0,661 \\
\hline GCG $\left(\mathrm{X}_{2}\right)$ & 0,907 & 0,881 & 0,660 \\
\hline Financial Performance $(\mathrm{Y})$ & 0,875 & 0,717 & 0,778 \\
\hline Firm Value $(\mathrm{Z})$ & 0,852 & 0,688 & 0,744 \\
\hline Ownership Structure $\left(\mathrm{X}_{3}\right)$ & 0,687 & 0,612 & 0,523 \\
\hline
\end{tabular}

A construct said to be reliable if the value of composite reliability above 0.50 (Jogiyanto \& Abdillah, 2009: 62). The values of reliability of composite for all constructs is above 0.5 which suggests that all constructs in the model at a reliable estimate meets the criteria. Value of reliability composite of the lowest is equal to 0,687 on Ownership Structure variable $\left(\mathrm{X}_{3}\right)$ and value reliability of composite the highest is equal to 0.907 at GCG variable $\left(\mathrm{X}_{2}\right)$. Reliability test can also be strengthened by Cronbach's Alpha where the suggested value is above 0.60 and the value of Cronbach's Alpha for all constructs were above 0.6. The lowest value is for 0,612 on ownership structure $\left(\mathrm{X}_{3}\right)$ and the highest is at 0,881 on GCG $\left(\mathrm{X}_{2}\right)$. Aside from the composite reliability and cronbach's alpha to assess the reliability of a construct can be done by looking at the Average Variance Extracted (AVE) and suggested above 0.50. The lowest value is for 0523 on ownership structure (X3) and the highest is at 0,778 on GCG $\left(\mathrm{X}_{2}\right)$. Based on Table 4 above it can be concluded that the value AVE of all constructs above 0.5 . 


\subsection{Inner models}

Inner model structural testing or models made to look at the relationship between the constructs, the significant value and R-square of the research model. Structural models were evaluated using 3 different methods of R-square for dependent constructs, $\mathrm{Q}^{2}$ and $\mathrm{GoF}$

a. Assessing R-square for each dependent latent variables.

Table 5. R-squre

\begin{tabular}{|l|c|}
\hline \multicolumn{1}{|c|}{ Measurement } & R-Square \\
\hline Financial Performance & 0,452 \\
\hline Firm Value & 0,326 \\
\hline
\end{tabular}

b. Assessing $Q^{2}$ with the formula

$$
\begin{aligned}
& =1-\left(1-\mathrm{R}^{2}\right)\left(1-\mathrm{R}^{2}\right) \\
& =1-(1-0,452)(1-0,326) \\
& =1-(0,594)(0,674) \\
& =0,60
\end{aligned}
$$

c. Finding the value of Goodness of Fit $(\mathrm{GoF})=\sqrt{ } \mathrm{AVE} \times \mathrm{R}^{2}$

$$
\begin{aligned}
& =\sqrt{ } 0,679 \times 0,389 \\
& =\sqrt{ } 0,264 \\
& =0,514
\end{aligned}
$$

According by Tenenhaus (2004), the value of small $\mathrm{GoF}=0.1$, GoF medium $=0.25$ and GoF great $=0$, 38. Of testing $\mathrm{R}^{2}, \mathrm{Q}^{2}$ and $\mathrm{GoF}$ seen that the models established are robust. So that hypothesis testing can be done. Based on the value of R-Square in the Table above shows the R-square value of the financial performance of 0,452. It means that $45,20 \%$ Financial Performance $(\mathrm{Y})$ can be affected by CSR $\left(\mathrm{X}_{1}\right)$ GCG $\left(\mathrm{X}_{2}\right)$ Ownership structure $\left(\mathrm{X}_{3}\right)$ and the firm value, while the remaining $54,80 \%$ influenced by other variables outside studied Rsquare value. Firm value $(Z)$ is equal to 0,326 . This means that $32.60 \%$ firm value $(Z)$ can be affected by variables CSR $\left(X_{1}\right)$, GCG $\left(X_{2}\right)$, ownership structure $\left(X_{3}\right)$ and Financial Performance, while $67.40 \%$ influenced by other variables outside under study, Another variable in question is a factor in economic conditions, technical factors and fundamentals of the company. The bases used in testing hypotheses are the value contained in the output path coefficients using data analysis Bootstrapping SmartPLS3 in the following figure:

Figure 2. Final Model

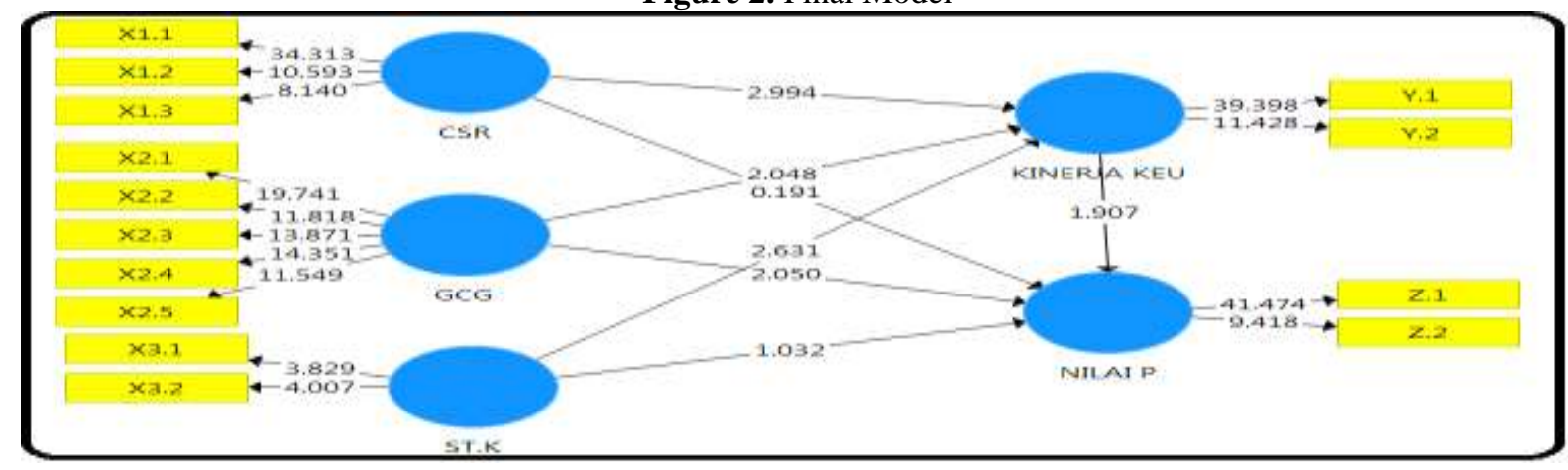

Significance parameters in the estimation provide very useful information about the relationship between the variables of the study.

Table 6. Path coefficients

\begin{tabular}{|l|c|c|c|c|c|}
\hline \multicolumn{1}{|c|}{ Measurement } & Original Sample (O) & Sample Mean (M) & $\begin{array}{c}\text { Standard } \\
\text { Deviation } \\
(\text { STDEV) }\end{array}$ & T- Statistic & P-Values \\
\hline CSR $\left(\mathrm{X}_{1}\right)$-> Financial Performance $(\mathrm{Y})$ & 0.379 & 0.362 & 0.126 & 3.003 & 0.003 \\
\hline CSR $\left(\mathrm{X}_{1}\right)$-> Firm Value $(\mathrm{Z})$ & 0.032 & 0.029 & 0.151 & 0.215 & 0.830 \\
\hline GCG $\left(\mathrm{X}_{2}\right)$ - Financial Performance $(\mathrm{Y})$ & 0.233 & 0.263 & 0.108 & 2.152 & 0.032 \\
\hline GCG $\left(\mathrm{X}_{2}\right)$-> Firm Value (Z) & 0.271 & 0.281 & 0.118 & 2.305 & 0.022 \\
\hline Ownership Structure $\left(\mathrm{X}_{3}\right)$-> F. Performance $(\mathrm{Y})$ & 0.220 & 0.223 & 0.081 & 2.703 & 0.007 \\
\hline
\end{tabular}


Effect of corporate social responsibility, good corporate governance and ownership structure on ..

\begin{tabular}{|l|l|l|l|l|}
\hline Ownership Structure $\left(\mathrm{X}_{3}\right)$-> Firm Value $(\mathrm{Z})$ & 0.138 & 0.146 & 0.131 & 1.052 \\
\hline Financial Performance $(\mathrm{Y})$-> Firm Value $(\mathrm{Z})$ & 0.264 & 0.262 & 0.132 & 1.998 \\
\hline
\end{tabular}

\subsection{Hypothesis Testing}

Analysis of direct effect to evaluate the effect of each construct to directly influence which is a coefficient of all coefficients lines with arrows one end, the test results are presented. To find out how big between variables, then do the analysis of the direct effect and the indirect effect as well as the total effect.

Table 7. Direct and indirect effect

\begin{tabular}{|c|c|c|c|c|c|c|c|}
\hline \multicolumn{3}{|c|}{ Variable } & \multirow[b]{2}{*}{ T-Statistic } & \multirow[b]{2}{*}{ Direct } & \multirow[b]{2}{*}{ Indirect } & \multirow{2}{*}{$\begin{array}{l}\text { Total } \\
\text { Effect }\end{array}$} & \multirow[b]{2}{*}{$\mathrm{p}$-value } \\
\hline Exogenous & Intervening & Endogenous & & & & & \\
\hline $\operatorname{CSR}\left(\mathrm{X}_{1}\right)$ & - & F. Performance (Y) & 3,003 & 0,379 & - & 0,379 & 0,003 \\
\hline $\operatorname{GCG}\left(\mathrm{X}_{2}\right)$ & - & F. Performance (Y) & 2,152 & 0,233 & - & 0,233 & 0,032 \\
\hline Ownership Structure $\left(\mathrm{X}_{3}\right)$ & - & F. Performance (Y) & 2,703 & 0,220 & - & 0,220 & 0,007 \\
\hline $\operatorname{CSR}\left(\mathrm{X}_{1}\right)$ & - & Firm Value (Z) & 0,215 & 0,032 & - & 0,032 & 0,830 \\
\hline $\operatorname{GCG}\left(\mathrm{X}_{2}\right)$ & - & Firm Value (Z) & 2,305 & 0,271 & - & 0,271 & 0,022 \\
\hline Ownership Structure $\left(\mathrm{X}_{3}\right)$ & - & Firm Value (Z) & 1,052 & 0,138 & - & 0,138 & 0,294 \\
\hline F. Performance (Y) & - & Firm Value (Z) & 1,998 & 0,264 & & 0,264 & 0,046 \\
\hline $\operatorname{CSR}\left(\mathrm{X}_{1}\right)$ & F. Performance (Y) & Firm Value (Z) & 1,026 & 0,032 & 0,100 & 0,132 & 0,306 \\
\hline $\operatorname{GCG}\left(\mathrm{X}_{2}\right)$ & F. Performance (Y) & Firm Value (Z) & 2,772 & 0,271 & 0,061 & 0.333 & 0,006 \\
\hline Ownership Structure $\left(\mathrm{X}_{3}\right)$ & F. Performance (Y) & Firm Value (Z) & 1,653 & 0,138 & 0,058 & 0.196 & 0,099 \\
\hline
\end{tabular}

Based on the conceptual framework and research model, then to see the effect of independent variables on the intervening variables (among) the dependent variable, the results of the analysis of the influence of CSR, corporate governance and ownership structure of the financial performance and firm value to Evaluate Structural Model or Inner Models with PLS obtained equation following:

- Effect of CSR, GCG and Ownership Structure (OS) on Financial Performance (FP)

$\mathrm{FP}=0,379 \mathrm{CSR}+0,233 \mathrm{GCG}+0,220 \mathrm{OS}+€_{1}$

- Effect of CSR, GCG, OS and Financial Performance (FP) On firm value (FV)

$\mathrm{PV}=0,032 \mathrm{CSR}+0,271 \mathrm{GCG}+0,138 \mathrm{OS}+0,264 \mathrm{FP}+\epsilon_{2}$

- Effect of CSR, GCG, OS On firm value (FV) as a mediated Financial Performance (FP)

$\mathrm{FV}=0,100 \mathrm{CSR}+0,061 \mathrm{GCG}+0,058 \mathrm{OS}+€$

1) Direct Effect

- $\mathrm{CSR}$ on $\mathrm{FP}(\mathrm{CSR} \rightarrow \mathrm{FP})=0,379$

- GCG on FP $(\mathrm{GCG} \rightarrow \mathrm{FP})=0,233$

- OS on FP $(\mathrm{OS} \rightarrow \mathrm{FP})=0,220$

- $\mathrm{CSR}$ on $\mathrm{FV}(\mathrm{CSR} \rightarrow \mathrm{FV})=0,032$

- $\mathrm{GCG}$ on $\mathrm{FV}(\mathrm{GCG} \rightarrow \mathrm{FV})=0,271$

- $\mathrm{OS}$ on $\mathrm{FV}(\mathrm{OS} \rightarrow \mathrm{FV})=0,138$

- $\mathrm{FP}$ on $\mathrm{FV}(\mathrm{FP} \rightarrow \mathrm{FV})=0,264$

2) Indirect Effect

- $\mathrm{CSR}$ on FV as a mediated FP $(\mathrm{CSR} \rightarrow \mathrm{FP} \rightarrow \mathrm{FV})=0,379 \mathrm{X} 0,264=0,100$.

- GCG on FV as a mediated FP $(\mathrm{GCG} \rightarrow \mathrm{FP} \rightarrow \mathrm{FV})=0,233$ X $0,264=0,061$

- $\mathrm{OS}$ on FV as a mediated FP $(\mathrm{OS} \rightarrow \mathrm{FP} \rightarrow \mathrm{FV})=0,220 \mathrm{X} 0,264=0,058$

3) Total Effect

$-\quad(\mathrm{CSR} \rightarrow \mathrm{FV}+\mathrm{CSR} \rightarrow \mathrm{FP} \rightarrow \mathrm{FV})=0,032+0,100=0,132$ 
$-\quad(\mathrm{GCG} \rightarrow \mathrm{FV}+\mathrm{GCG} \rightarrow \mathrm{FP} \rightarrow \mathrm{FV})=0,271+0,061=0,333$

$-\quad(\mathrm{OS} \rightarrow \mathrm{FV}+\mathrm{OS} \rightarrow \mathrm{FP} \rightarrow \mathrm{FV})=0,138+0,058=0,196$

\subsection{Analysis of Results}

\subsubsection{Effect of CSR on Financial performance}

Hypothesis $\left(\mathrm{H}_{1 \mathrm{a}}\right), \mathrm{CSR}$ is positive and significant effect on financial performance. The results of the analysis in Table 7 showed that CSR is positive and significant effect on the financial performance, the path coefficients of 0.379 and p-value is 0,003 . These results are consistent with the hypothesis $\left(\mathrm{H}_{1 \mathrm{a}}\right)$ proposed that CSR is positive and significant effect on financial performance. Thus Hypothesis $\left(\mathrm{H}_{1 \mathrm{a}}\right)$ CSR positive and significant impact on CSR can be accepted. This means that CSR provides a significant contribution on financial performance; this could mean that investors have a good perception of the CSR disclosure

\subsubsection{Effect of GCG on Financial Performance}

Hypothesis $\left(\mathrm{H}_{2 \mathrm{a}}\right)$ stated that GCG positive and significant effect on Financial Performance. The analytical result is presented in the table 7 shows that GCG positive and significant effect on financial performance. The path coefficient of 0.233 and p-value is 0,032 . These results are consistent with the hypothesis $\left(\mathrm{H}_{2 \mathrm{a}}\right)$ proposed that GCG positive and significant effect on financial performance. So the hypothesis $\left(\mathrm{H}_{2 \mathrm{a}}\right)$ which states GCG positive and significant effect on the financial performance can be acceptable. This means that good corporate governance contributes to financial performance.

\subsubsection{Effect of Ownership structure on Financial Performance}

Hypothesis $\left(\mathrm{H}_{3 \mathrm{a}}\right)$, ownership structure has a positive and significant effect on financial performance. The results of the analysis as Table 7 showed that the ownership structure has a positive and significant effect on financial performance. The path coefficients 0.220 and the p-value are 0.007 . These results are consistent with the hypothesis $\left(\mathrm{H}_{3 \mathrm{a}}\right)$ proposed that the ownership structure has a positive and significant effect on financial performance. Thus the hypothesis $\left(\mathrm{H}_{3 \mathrm{a}}\right)$ which states that the ownership structure has a positive and significant effect on the financial performance can be acceptable. This means that the ownership structure provides a significant contribution on financial performance.

\subsubsection{Effect of CSR on Firm Value}

Hypothesis $\left(\mathrm{H}_{1 \mathrm{~b}}\right), \mathrm{CSR}$ is positive and significant effect on firm value. The result of the analysis as Table 7 shows that CSR has a positive effect and insignificant effect on firm value. The path coefficients of 0.032 and the p-value of 0.306 or greater than 0.05 . These results are consistent with the hypothesis $\left(\mathrm{H}_{1 b}\right)$ proposed that CSR is positive and significant impact on the value of the company, so the hypothesis $\left(\mathrm{H}_{1 \mathrm{~b}}\right) \mathrm{CSR}$ positive and significant effect on firm value was rejected. This means that CSR does not provide a meaningful contribution to firm value.

\subsubsection{Effect of GCG on Firm Value}

Hypothesis $\left(\mathrm{H}_{2 \mathrm{~b}}\right), \mathrm{GCG}$ is a positive and significant effect on firm value. The results of the analysis, as in Table 7 shows that GCG positive and significant effect on firm value with a path coefficient 0.271 and the pvalue of 0.006 or less 0,05 . These results are consistent with Hypothesis $\left(\mathrm{H}_{2 \mathrm{~b}}\right)$ proposed that GCG positive and significant effect on firm value. Thus Hypothesis $\left(\mathrm{H}_{2 \mathrm{~b}}\right)$ which states $\mathrm{GCG}$ positive and significant effect on firm value company can be accepted. This means that the disclosure of corporate governance will contribute substantially to firm value.

\subsubsection{Effect of Ownership Structure on Firm Value}

Hypothesis $\left(\mathrm{H}_{3 \mathrm{~b}}\right)$, ownership structure is positive and significant effect on firm value. Results of the analysis is presented in Table 7 shows that the ownership structure is positive and significant effect on firm value by path coefficients of 0,138 and the p-value of 0.099 . These results are consistent with the hypothesis $\left(\mathrm{H}_{3 \mathrm{~b}}\right)$ proposed that ownership structure is positive and significant effect on firm value. Thus the hypothesis $\left(\mathrm{H}_{3 \mathrm{~b}}\right)$ Ownership Structure is positive and significant effect on firm value was rejected. This means that the ownership structure does not provide a meaningful contribution to firm value.

\subsubsection{Effect of Financial Performance on firm Value}

Hypothesis $\left(\mathrm{H}_{4}\right)$, financial performance is positive and significant effect on firm value. The result of the analysis, as in Table 7 shows that financial performance has a positive and significant effect on firm value. The path coefficient of 0,264 and the p-value of 0,046 or less than 0,05 . These results are consistent with the hypothesis $\left(\mathrm{H}_{4}\right)$ proposed that financial performance is a positive and significant effect on firm value. Thus the 
hypothesis $\left(\mathrm{H}_{4}\right)$ which stated that the financial performance has a positive and significant effect on firm value is acceptable. This means that the financial performances which increase will also increase the firm value.

\subsubsection{Effect of CSR on Firm Value as a mediated Financial Performance}

Hypothesis $\left(\mathrm{H}_{1 \mathrm{c}}\right)$, CSR is positive and significant effect on the firm value as a mediated financial performance. The results of the analysis, as in Table 7 show that CSR has a positive and significant effect and not to firm value with indirect effect amounting to 0,100 and the p-value of 0.306 . These results are not consistent with the hypothesis $\left(\mathrm{H}_{1 \mathrm{c}}\right)$ proposed that CSR is positive and significant effect on firm value as a mediated financial performance. Thus the hypothesis $\left(\mathrm{H}_{1 \mathrm{c}}\right)$ stated CSR positive and significant effect on firm value as a mediated financial performance. This means that CSR is not a meaningful contribution through the financial performance in enhancing the firm value.

\subsubsection{Effect of GCG on firm value as a mediated Financial Performance}

Hypotheses $\left(\mathrm{H}_{2 \mathrm{c}}\right)$, GCG positive and significant effect on firm value as a mediated financial performance. Results of the analysis is presented in Table 7 shows that GCG positive and significant effect on firm value as a mediated financial performance of the indirect effect amounting to 0.061 and the p-value of 0.006. These results are consistent with the hypothesis $\left(\mathrm{H}_{2 \mathrm{c}}\right)$ have been raised GCG positive and significant effect on firm value as a mediated financial performance, thus the hypothesis $\left(\mathrm{H}_{2 \mathrm{c}}\right)$ stated GCG positive and significant impact on firm value as a mediated financial performance can be acceptable. This means that GCG provides a significant contribution to firm value as a mediated financial performance

\subsubsection{Effect of Ownership Structure Corporate on Firm Value as a mediated Financial Performance}

Hypothesis $\left(\mathrm{H}_{3 \mathrm{c}}\right)$, ownership structure is positive and significant effect on firm value as a mediated financial performance. Results of the analysis is presented in Table 7 shows that the ownership structure has a positive and insignificant effect on firm value as a mediated financial performance of the indirect effect amounting to 0,058 and the p-value of 0.099 or greater than 0.05 . These results are not consistent with the hypothesis $\left(\mathrm{H}_{3 \mathrm{c}}\right)$ proposed that the ownership structure has a positive and significant effect on firm value as a mediated financial performance, thus the hypothesis $\left(\mathrm{H}_{3 \mathrm{c}}\right)$ which states that the ownership structure is a positive and significant impact on firm value as a mediated financial performance declined. This means that the ownership structure did not contribute significantly on firm value as a mediated financial performance.

\section{Conclusion}

Based on the analysis and the previous discussion, this study can be summarized as follows: (1) CSR index composed of indicators of Economic and environmental performance has a positive and significant effect on financial performance but is not positive and significant effect on firm value. CSR provides sufficient contribution to financial performance. because of the indicators of CSR disclosed, the index of disclosure already in value sufficient $>60 \%$ of the items of disclosure should be, so as to improve financial performance, but only short term while increasing the value of the company need the CSR programs of strategic and mediumterm and long-term so as to provide value added and the legitimacy of the company as a potential resource for the company to going concern and to create a corporate image in the increased value of companies listed on the Jakarta Islamic Index (JII); (2) GCG consisting of indicator index (structure and composition of the board of directors, ownership and shareholding, transparency, disclosure and audit, board remuneration and corporate ethics) is positive and significant effect on the financial performance and corporate value. This means that the disclosure of corporate governance contributes to financial performance and firm value; (3) the ownership structure that consists of managerial ownership, institutional ownership and public ownership is positive and no significant effect on financial performance but positive and significant effect on firm value. This means that the ownership structure is less contributed to the financial performance of companies listed in JII; (4) financial performance as measured by ROA and ROE is positive and significant effect on firm value. This means that the financial performance contributes to firm value, if the financial performance increases, it will increase the firm value of companies listed in JII; (5) GCG is positive and significant effect on firm value as a mediated financial performance, while CSR, and the ownership structure has a positive effect and no significant effect on firm value, either directly or through financial performance, this means that GCG can contribute to firm value as a mediated the financial performance whereas CSR and ownership structure cannot contribute to firm value.

\section{References}

[1] Anthony, Robert N. \& Vijay Govindarajan. (2005). Management Control Systems, Jakarta: Salemba Empat

[2] Anwar, Dwi Oktaviani \& Masodah. (2013). Effect of Corporate Value, CSR Disclosure on Financial performance As manajerial ownership a moderating variables. Journal of the University Gunadarma Depok.

[3] Ariyoto, K. (2000). Good Corporate Governance and Concept of Enforcement in BUMN and Business Environment. Management of Indonesian Entrepreneurs, (10), 10-13 
[4] Arsoy, A. P., Arabaci, Ö., \& Çiftçioglu, A. (2012). Corporate social responsibility and financial performance relationship: The case of Turkey. Muhasebe ve Finansman Dergisi, (53).

[5] Bauer, R., Frijns, B., Otten, R., \& Tourani-Rad, A. (2008). The impact of corporate governance on corporate performance: Evidence from Japan. Pacific-Basin Finance Journal, 16(3), 236-251.

[6] Bollen, L., Vergauwen, P., \& Schnieders, S. (2005). Linking intellectual capital and intellectual property to company performance. Management Decision, 43(9), 1161-1185.

[7] Brown, L. D., \& Caylor, M. L. (2006). Corporate governance and firm valuation. Journal of accounting and public policy, 25(4), 409-434.

[8] Crutchley, C. E., \& Hansen, R. S. (1989). A test of the agency theory of managerial ownership, corporate leverage, and corporate dividends. Financial Management, 36-46.

[9] Darmawati, D., Khomsiyah, K., \& Rahayu, R. G. (2005). Corporate Governance relationship and company performance. The Indonesian Journal of Accounting Research, 8 (1).

[10] Forum For Corporate Governance In Indonesia, FCGI. (2001) Corporate Governance: Corporate Governance. Third Edition. Jakarta

[11] Ghozali, Imam. (2011). Application of Multivariate Analysis with IBM SPSS Program 19. Prints IV. Semarang: Diponegoro University Publishing Agency

[12] Helfert, Erich A. (1996). Financial Analysis Techniques: Practical Hints for. Managing and Measuring Company Performance, Interpreting by Herman. Jakarta: Erlangga

[13] Jensen, M. C., \& Meckling, W. H. (1976). Theory of the firm: Managerial behavior, agency costs and ownership structure. Journal of financial economics, 3(4), 305-360.

[14] Klapper, L. F., \& Love, I. (2002). Corporate governance, investor protection and performance in emerging markets.

[15] Penman, Stephen, H. (2003), Financial Statement Analysis and Security Valuation, Second Edition, New York: Mc Graw Hill.

[16] Scott, William R. (2006). Financial Acconting theory. $4^{\text {th }}$ Edition. Canada Inc : Pearson Education.

[17] Shleifer, A., \& Vishny, R. W. (1997). A survey of corporate governance. The journal of finance, 52(2), 737-783.

[18] Syakhroza, Akhmad. (2003). Theory of Corporate Governance, Entrepreneur, No.08.Tahun XXXII, August

[19] Watts R. \& J.L. Zimmerman. (1986). Positive Accounting Theory. New York: Prentice Hall.

[20] Zaretta, B., \& Sitinjak, E. L. M. (2006). Corporate Governance Financial Aspects and Funding Decisions. Management of Indonesian Entrepreneurs, 35 (9), 36-44.

\footnotetext{
Amiruddin Jallo Effect of corporate social responsibility, good corporate governance and ownership structure on financial performance and firm value: A Study in Jakarta Islamic Index.” IOSR Journal of Business and Management (IOSR-JBM), vol. 19, no. 11, 2017, pp. 64-75.
} 